\section{Apple's ResearchKit frees medical research}

Lost in the excitement generated by the unveiling of the Apple Watch was the launch of an iPhone feature called ResearchKit, a software tool that could shake up data gathering for medical research. ResearchKit is designed to encourage the 7 million iPhone users around the world to sign up and participate directly in research. It "could revolutionize medical studies," according to Apple, by increasing the pool of research subjects and the ease of collecting data and interaction with patients. Apple has already released five ResearchKit apps that link users to studies on Parkinson's disease, diabetes, asthma, breast cancer and heart disease. The software collects participants' information as they go about their daily lives, rather than in a laboratory, and feeds the data directly back to medical researchers. High-profile institutions have already signed up to use this open-source platform: University of Rochester, New York; Xuanwu Hospital in Beijing; Sage Bionetworks, based in Seattle; Massachusetts General Hospital, based in Boston; Stanford University in California; the University of Oxford in Oxford, UK; Mount Sinai Hospital and Weill Cornell Medical College, both in New York; the Dana-Farber Cancer Institute in Boston; the UCLA School of Public Health in Los Angeles; and Penn Medicine in Philadelphia. The ResearchKit will sit alongside Apple's Health app, which gives iPhone users an easy-to-read dashboard of their health and fitness data. A developer tool called HealthKit will allow further development of compatible third-party apps.

"This result will be life-changing for
many women living with mitochondrial
disease, giving them the precious
chance to bear unaffected children, removing
the condition from a family line and reducing
the numbers faced with its devastating
effects." Robert Meadowcroft, chief executive
of the Muscular Dystrophy Campaign,
speaking of the approval by the UK
Parliament of embryos with three biological
parents. (Newsday, 24 February 2015)
"[The decision is] a historic mistake
[that would] turn children into biological
experiments and sell wildly exaggerated hope
to women already in a challenging position."
A spokesperson for the Center for Genetics
and Society, speaking of the approval by
the UK Parliament of three-parent embryos.
(Newsday, 24 February 2015 )
"No company, no doctor, no patient ever
expected this. It makes you wonder where
this is all going and not just among pregnant
women." Eric Topol from The Scripps
Research Institute, commenting on the
announcement by Sequenom, a provider
of noninvasive prenatal testing, that they
detected cancer in at least 25 pregnant
women. (BuzzFeed, 5 March 2015 )

Table 1 Selected IDO/TDO targeting therapies

\begin{tabular}{|c|c|c|c|c|}
\hline Molecule & Developer & Partner(s) & Deal terms & Clinical status \\
\hline $\begin{array}{l}\text { Epacadostat } \\
\text { (INCB24360) }\end{array}$ & Incyte & $\begin{array}{l}\text { Nonexclusive clinical col- } \\
\text { laborations with Advaxis } \\
\text { (Princeton, New Jersey), } \\
\text { AstraZeneca (London), } \\
\text { BMS, Genentech } \\
\text { (Roche, Basel) \& Merck } \\
\text { (Kenilworth, New Jersey) }\end{array}$ & Undisclosed & Phase 2 \\
\hline Indoximod & $\begin{array}{l}\text { NewLink } \\
\text { Genetics }\end{array}$ & Unpartnered & Not applicable & Phase 2 \\
\hline NLG919 & $\begin{array}{l}\text { NewLink } \\
\text { Genetics }\end{array}$ & Genentech & $\begin{array}{l}\text { License agreement, } \\
\$ 150 \text { million upfront } \\
\text { plus } \$ 1 \text { billion mile- } \\
\text { stones }\end{array}$ & Phase 1 \\
\hline F001287 & $\begin{array}{l}\text { Flexus } \\
\text { Biosciences }\end{array}$ & BMS & $\begin{array}{l}\text { Acquisition, } \$ 800 \text { mil- } \\
\text { lion upfront plus } \$ 450 \\
\text { million development } \\
\text { milestones }\end{array}$ & Preclinical \\
\hline $\begin{array}{l}\text { Undisclosed } \\
\text { IDO1 \& TDO2 } \\
\text { inhibitors }\end{array}$ & $\begin{array}{l}\text { iTeos } \\
\text { Therapeutics }\end{array}$ & Pfizer (New York) & $\begin{array}{l}€ 24(\$ 35) \text { million } \\
\text { upfront plus undis- } \\
\text { closed milestones, } \\
\text { equity investment and } \\
\text { research funding }\end{array}$ & Preclinical \\
\hline $\begin{array}{l}\text { Undisclosed } \\
\text { IDO, TDO } \\
\text { inhibitors \& } \\
\text { dual IDO/TDO } \\
\text { inhibitors }\end{array}$ & $\begin{array}{l}\text { IOmet } \\
\text { Pharma } \\
\text { (Edinburgh) }\end{array}$ & Unpartnered & Not applicable & Preclinical \\
\hline
\end{tabular}

(signal transducer and activator of transcription) signaling system in mediating interferon$\gamma$-induced IDO expression. "It's obviously been an active area of preclinical research for us for several years," Huber said. A clinical trial based on the treatment concept will get underway this year, which will provide yet another insight into the role of IDO inhibition in cancer immunotherapy.

In the liver, a tryptophan 2,3-dioxygenase (TDO) catalyzes the same reaction and may offer an alternative target. "We have identified two cancers where TDO could be highly relevant," iTeos' Detheux says. BMS is also gaining a TDO inhibition program, from Flexus, as well as a series of dual IDO1-TDO inhibitors.

Although the potential utility of IDO inhibitors lies in their ability to block tumor escape from a T-cell response, Munn and his collaborators, Andrew Mellor, professor of medicine at GRU and Theodore Johnson assistant professor of pediatrics at GRU-who are consultants to NewLink Genetics-have recently described a second mechanism that may operate in certain settings. They found that IDO inhibition led to complement deposition in a mouse model of glioblastoma-but only when the therapy was co-administered with chemo- and radiotherapy (J. Immunother.
Cancer doi:10.1186/2051-1426-2-21, 7 July 2014). "Complement deposition only seems to occur inside the tumor," says Johnson. "This inflammatory process is able to damage the tumor and leads to a survival benefit in the mouse model." The group has seen similar effects in a melanoma model, he adds.

The complexity of IDO biology was further underlined in a recent study, on which Mellor was co-author, which uncovered an unexpected link between IDO activity and bone resorption, through the CTLA-4-CD80/86 T-cell co-stimulation system (Sci. Transl. Med. 6, 235ra60, 2014). Osteoclasts-the cells responsible for bone resorption-share a common lineage with antigen-presenting cells, and osteoclast precursors also express the CD80/86 co-stimulatory ligands on their surface. The study, in mice and human cells, found that CTLA-4 binding to CD80/86, which, in the immune system dampens T-cell activation, led to activation of IDO in osteoclast precursors, followed by apoptosis. That observation raises the possibility that long-term IDO inhibition or, indeed, CTLA-4 inhibition, could have negative consequences for bone health. "It's got very important implications that should not be neglected," Mellor says.

Cormac Sheridan Dublin 